\title{
Testing Students' Entrepreneurial Self-Efficacy as an Early Predictor of Entrepreneurial Activities. Evidence from the SEAS Project
}

\section{Krzysztof Zięba and Jakub Golik ${ }^{2}$}

\begin{abstract}
Over the last forty years, since Bandura (1977) introduced the concept of selfefficacy, there have been a constantly growing number of research publications using this concept. Its early development resulted in the creation of a new construct of entrepreneurial self-efficacy (ESE) proposed for the first time by (Chen et al. 1998). Since then, many different groups of research concerning ESE have emerged - one of them is the study of ESE of students. With regard to this particular group, a recent tendency to study ESE in a pre-post setting can be noticed i.a. Karlsson, Moberg (2013), Shinnar, Hsu, Powell (2014), Ismail, Zain, Zulihar (2015).

Due to the increasing interest in entrepreneurial self-efficacy research and the need to fill the gap in the literature with regard to European post-communist countries (and particularly - Poland) (Drnovsek, Wincent, Cardon, 2010), in this paper we present a brief overview of ESE research and pose the question whether ESE of Polish students can serve as an early predictor of their subsequent entrepreneurial activities, potentially leading them to nascent entrepreneurship.

The research material was collected from the SEAS (Survey on Entrepreneurial Attitudes of Students) Project carried out at the Faculty of Management and Economics, Gdańsk University of Technology. The research sample was composed of 72 students - ESE was measured in a pre-post setting using a single item based on a five-point Likert scale. One of the research conclusions is that ESE manifested by student-beginners seems to influence their later entrepreneurial behavior in a statistically significant way - potentially making ESE a valuable early predictor of future entrepreneurial activities. In the concluding part of the study, limitations are discussed and future study developments are indicated.
\end{abstract}

Keywords: self-efficacy, entrepreneurial self-efficacy, entrepreneurship.

\footnotetext{
1 Krzysztof Zięba, Ph.D., D.Sc., Faculty of Management and Economics, Gdansk University of Technology, Traugutta Str. 79, 80-233 Gdańsk, Poland, e-mail: krzysztof.zieba@zie.pg.gda.pl.

2 Jakub Golik, M.Sc., Faculty of Management and Economics, Gdansk University of Technology,

Traugutta Str. 79, 80-233 Gdańsk, Poland, e-mail: jakub.golik@pg.edu.pl.
} 


\section{INTRODUCTION}

The notion of self-efficacy has been extensively studied over the last 40 years. The term at the very beginning was deeply rooted in psychological theories. It has gained wide recognition among scientists after the publication of Bandura (1977) who defined it on the basis of his social learning theory as an individual's belief in his or hers capability of performing a given task (Boyd \& Vozikis, 1994). Self-efficacy is rooted in social cognitive theory which states that human behavior can be perceived as a function constituting personal, behavioral and environmental determinants (Coleman \& Kariv, 2013).

Since Bandura's publication, self-efficacy has been the subject of research and comparison with other psychological constructs. One such construct similar to self-efficacy is the locus of control. The main difference between them is the level of generality. The latter is a more general concept which refers to a wide variety of situations. It consists of internal locus of control, where one's belief is that rewards are based on an individual's behavior, and the external locus of control, where one's belief is that rewards are controlled by outside factors. In contrast to this notion, self-efficacy refers to the specific task and situation. Hence, an individual might be characterized by a strong internal locus of control while having low self-efficacy regarding a particular task (Boyd \& Vozikis, 1994). This contextuality of self-efficacy should be stressed as an important feature of this notion, as it leads to the conclusion that self-efficacy cannot be generalized across various fields of application.

In the early stage of development of research concerning self-efficacy, scientists concluded that it is a multidimensional construct. Furthermore, the connection between self-efficacy and notions related to entrepreneurship was found. By applying the work of Bandura to the concept of entrepreneurship, the more specific notion of entrepreneurial self-efficacy (ESE) was created (Coleman \& Kariv, 2013).

The main research question of this paper is whether students' entrepreneurial self-efficacy can serve as an early predictor of their current and future entrepreneurial activities. We start by presenting a brief overview of entrepreneurial self-efficacy research which offers a background to the stated research problem. Empirical data gathered within the framework of the SEAS project allowed us to address this question with regard to Polish students.

\section{LITERATURE REVIEW}

The formal construct of entrepreneurial self-efficacy was proposed for the first time by Chen, Green and Crick (1998). Their motivation for introducing 
the concept was due to the fact that previous research on psychology of entrepreneurs failed to distinguish managers from entrepreneurs on the basis of characteristics such as the above-mentioned locus of control. By presenting entrepreneurial self-efficacy, they intended to find an individual characteristic that is distinctively entrepreneurial (Chen, Green \& Crick, 1998). Entrepreneurial self-efficacy was defined as "the strength of a person's belief that he or she is capable of successfully performing the various roles and tasks of entrepreneurship." It was a multidimensional construct consisting of five factors: marketing, innovation, management, risk-taking, and financial control.

The work by Chen, Green and Crick (1998) at the same time defined, in a sense, the trend of research of entrepreneurial self-efficacy. They studied among others the relation between entrepreneurial self-efficacy and entrepreneurial intentions. The research was conducted on two groups: among students and small business executives. Many of the following studies on this matter were based on these target groups and measured similar relations.

After the introduction of entrepreneurial self-efficacy, both the general and entrepreneurial self-efficacy notions were discussed in scientific papers with regard to other psychological theories and concepts. For instance, Markman, Balkin and Baron (2002) measured general self-efficacy and regretful thinking on 217 patent inventors and showed that both of these determinants distinguish technological entrepreneurs from technological non-entrepreneurs. On the other hand, Arora, Haynie and Laurence (2011), on the basis of social cognition theory, investigated the relationship between counterfactual thinking and entrepreneurial self-efficacy, implying that "counterfactual thinking for entrepreneurial self-efficacy is moderated by individual differences based on the dispositional attributes of the entrepreneur." Some works also incorporated the Theory of Planned Behavior as their theoretical research basis for studies regarding prior family exposure to entrepreneurial intent (Carr \& Sequeira, 2007) or impact of entrepreneurship education (Maresch, Harms, Kailer \& Wimmer-Wurm, 2016). Finally, Hsu, Wiklund and Cotton (2017) contrasted two theories - SelfEfficacy Theory and Prospect Theory in a model determining an individual's intention to re-enter entrepreneurship following a business exit.

Among many publications regarding entrepreneurial self-efficacy, a group of research concerning relations or mediating role of entrepreneurial self-efficacy can be distinguished. For instance, Oyugi (2015) studied the mediating role of entrepreneurial self-efficacy on the relationship between entrepreneurial education and entrepreneurial intentions of university students. He concluded his research by stating that there exists a significant relationship between entrepreneurship education and entrepreneurial intention. However, selfefficacy only partially mediated these factors. The study on the effects of 
emotional intelligence on entrepreneurial intention and self-efficacy made by Mortan, Ripoll, Carvalho and Bernal (2014) showed that emotional intelligence positively affects entrepreneurial self-efficacy. Tsai, Chang and Peng (2016) studied a link between entrepreneurial self-efficacy and entrepreneurial intention involving the previously mentioned Theory of Planned Behavior. There are also many other works involving study on entrepreneurial selfefficacy and entrepreneurship intention i.a., Piperopoulos and Dimov (2015), Wang, Chang, Yao and Liang (2016), Klyver and Thornton (2010).

Densberger (2014) explored the relationship between entrepreneurs' self-efficacy and risk propensity by analyzing data from semi-structured, in-person interviews (49 entrepreneurs from three American cities). Her study indicated that high levels of self-efficacy result in entrepreneurs being comfortable with risk-taking. Another example of exploring different relations is the work by Pollack, Burnette and Hoyt (2012) which studied mind-set impact on self-efficacy in the face of threats to entrepreneurial success.

Other scientists have studied the connection between entrepreneurial self-efficacy and firms' performance. Cumberland, Meek and Germain (2015) carried out a more detailed study using a multidimensional attitude of investigating the impact of five entrepreneurial self-efficacy dimensions (Chen, Green \& Crick, 1998) on firms' performance. In particular, the study was focused on a franchise context which is understudied in entrepreneurial literature (Cumberland, Meek \& Germain, 2015). Another research by Coleman and Kariv (2013) also used a multidimensional approach to study the entrepreneurial self-efficacy impact on firms' performance.

Entrepreneurial self-efficacy has also been studied in the context of culture (e.g., Wennberg, Pathak \& Autio, 2013; Klyver \& Thornton, 2010). The former study had a sample of 42 countries while the latter was based on a random sample survey of 51 countries. Some more theoretical works also concerned methodology (e.g., Barakat, Boddington \& Vyakarnam, 2014 based on the CAL4INO ${ }^{3}$ project, or Drnovsek, Wincent \& Cardon, 2010).

Finally, the group concerning research of entrepreneurial self-efficacy on students at various educational stages should be mentioned. In this group two subcategories can be distinguished: research concerning primary and secondary school students (e.g., Studdard, Dawson \& Jackson, 2013; Lope Pihie $\&$ Bagheri, 2011) and research concerning university students (distinguishing students who had an entrepreneurship course and those who did not e.g., Maresch, Harms, Kailer \& Wimmer-Wurm, 2016; Setiawan, 2014).

3 CAL4INO stands for Creative Activities in Learning for Innovation. It is a project funded by the European Union whose main focus is to identify the impact of different types of creative learning activities on the innovation potential of its participants. The project is focused on universities in 6 participant EU countries.

Project Reference: 512448-LLP-1-2010-1-LV-KA1-KA1SCR 
In general, among studies concerning research of entrepreneurial selfefficacy on students, two trends can be noticed. The majority of articles concerns entrepreneurship education - its effects, flaws and possible improvements (e.g., Karlsson \& Moberg, 2013; Piperopoulos \& Dimov, 2015; Abaho, Olomi \& Urassa, 2015; Izquierdo \& Buelens, 2011; Shinnar, Hsu \& Powell, 2014) or works by Bagheri and Pihie (2011, 2013, 2013). The second recognized group of articles concerns mostly entrepreneurship intention with less attention paid to the entrepreneurship education process (e.g., Yasruddin et al., 2011; Rachmawan, Lizar \& Mangundjaya, 2015; Franco, Haase \& Lautenschlager, 2010; Carr \& Sequeira, 2007 or Krecar \& Coric, 2013).

Among this specific group of studies it should be noted that many publications come from Asian countries, for example, Malaysia: Lope Pihie and Bagheri (2011), Yasruddin et al. (2011), and Indonesia (Setiawan, 2014; Rachmawan, Lizar \& Mangundjaya, 2015). This fact is of great importance in view of the conclusions of previously mentioned studies of Wennberg, Pathak and Autio (2013) and Klyver and Thornton (2010). They showed that self-efficacy is correlated with cultural practices and cultural legitimacy of entrepreneurship respectively. It implies that there is a need for more locally focused studies in other parts of the world, especially as most studies on this subject seem to be focused on either Asian countries or less developed countries like Uganda (Oyugi, 2015; Abaho, Olomi \& Urassa, 2015).

In accordance with what was suggested by Krecar and Coric (2013), that "entrepreneurial self-efficacy is a dynamic construct which changes along with entrepreneurial status", a recent tendency to study entrepreneurial self-efficacy in a pre-post setting can be noticed i.a., Karlsson and Moberg (2013), Shinnar, Hsu and Powell (2014), Ismail, Zain and Zulihar (2015). Such an approach seems to be necessary in order to measure the development of entrepreneurial self-efficacy of students itself with regard to entrepreneurial education, as well as to study the impact of other relations involving, for instance, prior family business exposure (Carr \& Sequeira, 2007). Furthermore, the necessity of pre-post setting studies in this context can also be supported by the characteristic determinants of the life period of being a student. It first and foremost entails gaining a legal personality which enables young adults to start their own business. External factors, such as a dynamic market environment, make the students' career choice inevitable at this age, thus under particular circumstances, the possibility of being selfemployed is deliberated. All of these, combined with internal factors such as the enhanced emotional and intellectual development of students, make the subject of measuring entrepreneurial self-efficacy important in terms of a better understanding and improvement of methodology (Drnovsek, Wincent \& Cardon, 2010), as well as formulating guidelines for entrepreneurship 
education improvement as suggested by Din, Anuar and Usman (2016). Both of these research directions may improve our understanding of the entrepreneurial intentions of young people and as a result, bring insight to the current trends of creating micro and small enterprises. Our research acknowledges the current research trends in the studies concerning entrepreneurial self-efficacy while at the same time contributing to the literature results based on an example of a European post-communist country which remains an understudied topic (Drnovsek, Wincent and Cardon, 2010).

\section{RESEARCH METHODS}

Following the previously mentioned increasing interest in entrepreneurial self-efficacy research and the need to fill the gap with regard to European post-communist countries (and particularly - Poland), we pose the question whether entrepreneurial self-efficacy of Polish students can serve as an early predictor of their subsequent entrepreneurial activities, potentially leading them to nascent entrepreneurship. In order to answer this question, empirical data is needed. We decided to use research material collected within the SEAS Project, which is being carried out at the Faculty of Management and Economics (FM\&E), Gdańsk University of Technology (GUT). The data used in the research have been collected and analyzed personally (primary source) as both authors are involved in the project.

The SEAS (Survey on Entrepreneurial Attitudes of Students) Project started in 2008 as a longitudinal study of students' entrepreneurship, its determinants and antecedents combined with career choice study, education process evaluation and other student-related issues. The SEAS Project is realized in a form of an annual quantitative study. Data is collected with the use of a questionnaire which is administered to two groups of students: those who start their studies at FM\&E (the incoming sample) and those who are about to graduate (the outgoing sample).

An individual ID is assigned to all new students participating in the SEAS Project, which allows SEAS researchers to compare both samples not only on a general "sample level," but also with regard to individual changes that take place. This is a very important feature of the SEAS Project as such individual changes may be invisible from the sample level ${ }^{4}$.

\footnotetext{
4 Sometimes individual changes may not be recorded on the sample level, as they are "covered" by similar changes in the opposite direction. Let us consider the following situation: in the incoming sample $40 \%$ of students want to start their own business. During their three-year period of studies $20 \%$ become discouraged from starting a business, but another $20 \%$ get encouraged. Examination of the outgoing sample would show that nothing changed over the time of studies and still $40 \%$ of students want to become business owners. Tracing individual decisions would reveal that the composition of the seemingly stable (all the time $40 \%$ ) group of future entrepreneurs is different and there is no stability here at all.
} 
The incoming sample of management engineering students was examined in 2013 and after three years, in 2016, the same group of students was examined as the outgoing sample. The incoming sample consisted of 147 students. Three years later the questionnaire for the outgoing sample was completed by a smaller number of students, the difference being the result of changes in students status (some gave up, others had to repeat a semester) and limited availability (many students moved to study abroad within the Erasmus framework). 72 properly completed questionnaires were gathered in the outgoing sample and were comparable enough to be used for the purposes of our research.

Entrepreneurial self-efficacy was measured using a single item based on a five-point Likert scale in both the incoming and the outgoing sample and made a dichotomous variable. Using $\chi 2$ as a test of association we checked whether students showing self-efficacy at the time of starting their studies (the incoming sample) are more likely to manifest entrepreneurial activities upon completing their studies three years later (the outgoing group). Looking for an even stronger predictor, we also analysed changes of entrepreneurial self-efficacy over the period of studies and compared the obtained results.

\section{RESULTS AND ANALYSIS}

The first analyzed factor was entrepreneurial self-perception of the examined students. Entrepreneurial self-perception is often used to identify potential entrepreneurs (Zięba, 2015) and is related to further entrepreneurial activities, possibly leading to starting an own business. The examined students generally perceived themselves as entrepreneurial individuals. As shown in Table 1, 65\% of them share this opinion.

Table 1. Entrepreneurial self-efficacy as an early predictor of entrepreneurial self-perception of students

\begin{tabular}{lllllll}
\hline $\begin{array}{l}\text { Entrepreneurial } \\
\text { self-perception }\end{array}$ & ESE & & \multicolumn{3}{c}{ Total: } \\
& No & & Yes & & & \\
& {$[\mathrm{n}]$} & {$[\%]$} & {$[\mathrm{n}]$} & {$[\%]$} & {$[\mathrm{n}]$} & {$[\%]$} \\
\hline No & 17 & 52 & 8 & 21 & 25 & 35 \\
Yes & 16 & 48 & 31 & 79 & 47 & 65 \\
\hline Total: & 33 & 100 & 39 & 100 & 72 & 100 \\
\hline p-value $=0,00590$ (x2 test) & & & & & &
\end{tabular}

$p$-value $=0,00590$ ( $\chi 2$ test) 
However, entrepreneurial self-efficacy (ESE) examined three years earlier relates to a higher probability of entrepreneurial self-perception. Among students characterized by ESE (ESE group) nearly $80 \%$ believe they are entrepreneurial individuals, as opposed to $48 \%$ in the other (non-ESE) group. There is also a vast difference between the ESE and non-ESE group with regard to the current occupation of the students. Generally, most of the students (63\%) were working (full time or part-time). $33 \%$ of students were fully devoted to studying and they were not working. $4 \%$ of students (three people) were already business owners - see Table 2 .

Table 2. Entrepreneurial self-efficacy and current occupation of students

\begin{tabular}{|c|c|c|c|c|c|c|}
\hline \multirow{3}{*}{$\begin{array}{l}\text { Current } \\
\text { occupation }\end{array}$} & \multicolumn{4}{|l|}{ ESE } & \multicolumn{2}{|c|}{ Total: } \\
\hline & No & & Yes & & & \\
\hline & [n] & [\%] & [n] & [\%] & {$[\mathrm{n}]$} & [\%] \\
\hline Not working & 16 & 48 & 8 & 21 & 24 & 33 \\
\hline Working & 17 & 52 & 28 & 72 & 45 & 63 \\
\hline Owning a business & 0 & 0 & 3 & 8 & 3 & 4 \\
\hline Total: & 33 & 100 & 39 & 100 & 72 & 100 \\
\hline
\end{tabular}

p-value $=0,02214$ ( $\chi 2$ test for "working" and "not working" categories only)

Interestingly, students characterized by ESE were more likely to work (72\%) in comparison with their non-ESE counterparts (52\%). This may be seemingly surprising as working for someone does not seem very entrepreneurial but a more thorough analysis will show there is no contradiction here. What should be noted is the fact that all business owners belonged to the ESE group.

Having a business idea is a corner stone of the start-up process. Finding and refining a business idea is one of the most frequently taken steps towards becoming an entrepreneur. The data in Table 3 confirm that entrepreneurial self-efficacy favors entrepreneurial thinking and the resulting generation of a business idea. $67 \%$ of students who had been characterized by ESE at the time of the start of their studies possessed a business idea when they graduated from the university three years later. The share of non-ESE students having a business idea is significantly lower (less than $40 \%$ ).

Table 3. Entrepreneurial self-efficacy and business idea generation

\begin{tabular}{lllllll}
\hline Business idea generation & ESE & & & & Total: \\
& No & & Yes & & \\
& {$[\mathrm{n}]$} & {$[\%]$} & {$[\mathrm{n}]$} & {$[\%]$} & {$[\mathrm{n}]$} & {$[\%]$} \\
\hline Not having a business idea & 20 & 61 & 13 & 33 & 33 & 46 \\
\hline
\end{tabular}




\begin{tabular}{lllllll}
\hline & ESE & & & & Total: \\
Business idea generation & No & & Yes & & & \\
& {$[\mathrm{n}]$} & {$[\%]$} & {$[\mathrm{n}]$} & {$[\%]$} & {$[\mathrm{n}]$} & {$[\%]$} \\
\hline Having a business idea & 13 & 39 & 26 & 67 & 39 & 54 \\
\hline Total: & 33 & 100 & 39 & 100 & 72 & 100 \\
\hline p-value $=0,02066$ (x2 test) & & & & &
\end{tabular}

Early ESE is also able to explain the future plans of students with regard to setting up their own business. The declared ability to successfully run their own business is manifested through their intention to set up a business: the share of those intending to start own business in the ESE group was twice as big as in the non-ESE group ( $54 \%$ and $27 \%$ respectively).

Table 4. Entrepreneurial self-efficacy and plans to set up own business

\begin{tabular}{lllllll}
\hline & \multicolumn{3}{l}{ ESE } & \multicolumn{5}{c}{ Total: } \\
Plans regarding setting up own business & $\begin{array}{l}\text { No } \\
{[\mathrm{n}]}\end{array}$ & {$[\%]$} & $\begin{array}{l}\text { Yes } \\
{[\mathrm{n}]}\end{array}$ & {$[\%]$} & {$[\mathrm{n}]$} & {$[\%]$} \\
\hline Not planning to set up own business & 23 & 70 & 15 & 38 & 38 & 53 \\
Planning to set up own business in a few years & 9 & 27 & 21 & 54 & 30 & 42 \\
Already owning a business & 0 & 0 & 3 & 8 & 3 & 44 \\
No answer & 1 & 3 & 0 & 0 & 1 & 1 \\
\hline Total: & 33 & 100 & 39 & 100 & 72 & 100 \\
\hline
\end{tabular}

p-value $=0,01228$ ( $\chi 2$ test for "not planning" and "planning" categories only)

Those who planned to start their business in a few years' time can be divided into two groups. The first one was composed of people who state they will start their business in the near future (less than three years), the other one consisted of people who say that they need more professional experience and only after gaining a few years ${ }^{5}$ of experience would they set up own business. Taking this into account it is easy to understand why many students from the ESE group were working at the time of the research (see Table 2). This is simply consistent with their need to gather professional experience before they set up a business.

SEAS participants were also asked about their future career choice. Namely, the students were supposed to say how they imagine their professional situation to be in fifteen years. The results obtained (presented in Table 5) are quite consistent with those in Table 4.

5 The respondents choosing this option were asked to specify how many years of experience they would need. The average value was approximately five years. 
Table 5. Entrepreneurial self-efficacy and future career choice

\begin{tabular}{lllllll}
\hline Future career choice & \multicolumn{1}{c}{ ESE } & & \multicolumn{3}{c}{ Total: } \\
& $\begin{array}{l}\text { No } \\
{[\mathrm{n}]}\end{array}$ & {$[\%]$} & $\begin{array}{l}\text { Yes } \\
{[\mathrm{n}]}\end{array}$ & {$[\%]$} & {$[\mathrm{n}]$} & {$[\%]$} \\
\hline Business owner & 10 & 30 & 22 & 56 & 32 & 44 \\
Hired employee & 16 & 48 & 12 & 31 & 28 & 39 \\
Other and no answer & 7 & 21 & 5 & 13 & 12 & 17 \\
\hline Total: & 33 & 100 & 39 & 100 & 72 & 100 \\
\hline p-value=0,04346 (x2 test for "business owner" and "hired employee" categories only) &
\end{tabular}

Entrepreneurial self-efficacy is, as was mentioned before, a dynamic construct. It may change over time, especially when students are subject to influence consistent with typical sources of self-efficacy, as defined by Bandura (1977). Two sources are, to a large extent, related to one's own experience (i.e., previous success and psychological factors) and the remaining two are related to external factors (i.e., modeling and social persuasion). All those sources are likely to be at play with regard to students. Nevertheless, the changes in ESE within the examined sample are not very significant over the period of three years.

Table 6. Changes in entrepreneurial self-efficacy over time

\begin{tabular}{llllllll}
\hline Initial and final & \multicolumn{3}{c}{ ESE } & & & Total: \\
entrepreneurial & & No & & Yes & & & \\
self-efficacy & & {$[\mathrm{n}]$} & {$[\%]$} & {$[\mathrm{n}]$} & {$[\%]$} & {$[\mathrm{n}]$} & {$[\%]$} \\
\hline Final ESE & No & 22 & 67 & 9 & 23 & 32 & 43 \\
& Yes & 11 & 33 & 30 & 77 & 28 & 57 \\
\hline Total: & & 33 & 100 & 39 & 100 & 72 & 100 \\
\hline p-value $=0,00020(x 2$ test) & & & & & & &
\end{tabular}

$p$-value $=0,00020$ ( $(2$ test $)$

$77 \%$ of the students belonging to the ESE group at the beginning of their studies were still characterized by ESE three years later. $23 \%$ lost their ESE at that time. The lack of ESE is also a relatively stable characteristic. $67 \%$ of those lacking ESE as student beginners also lacked ESE upon their graduation. One-third of the non-ESE group gained entrepreneurial self-efficacy during their studies.

Since most of the students did not change with regard to their ESE, we focused on those permanently characterized and permanently not characterized by ESE to check whether persistent presence of ESE as compared to persistent lack of it may be a stronger predictor of entrepreneurial activities of students graduating from the university. As can be seen in Table7 and Table 8, both entrepreneurial 
self-perception and current occupation of students are significantly dependent on the question whether they constantly possess ESE or not.

Table 7. Persistent entrepreneurial self-efficacy and entrepreneurial self-perception of students

\begin{tabular}{lllllll}
\hline \multirow{2}{*}{$\begin{array}{l}\text { Entrepreneurial } \\
\text { self-perception }\end{array}$} & \multicolumn{2}{l}{$\begin{array}{l}\text { Persistent } \\
\text { lack of ESE }\end{array}$} & \multicolumn{2}{l}{$\begin{array}{l}\text { Persistent } \\
\text { presence of ESE }\end{array}$} & Total: & \\
& {$[\mathrm{n}]$} & {$[\%]$} & {$[\mathrm{n}]$} & {$[\%]$} & {$[\mathrm{n}]$} & {$[\%]$} \\
\hline No & 14 & 64 & 5 & 17 & 19 & 37 \\
Yes & 8 & 36 & 25 & 83 & 33 & 63 \\
\hline Total: & 22 & 100 & 30 & 100 & 52 & 100 \\
\hline p-value $=0,00051$ (x2 test) & & & & & &
\end{tabular}

Table 8. Persistent entrepreneurial self-efficacy and current occupation of students

\begin{tabular}{lllllll}
\hline \multirow{2}{*}{$\begin{array}{l}\text { Current } \\
\text { occupation }\end{array}$} & \multicolumn{2}{l}{$\begin{array}{l}\text { Persistent } \\
\text { lack of ESE }\end{array}$} & \multicolumn{2}{l}{ Persistent } & \multicolumn{2}{l}{ Total: } \\
& {$[\mathrm{n}]$} & {$[\%]$} & {$[\mathrm{n}]$} & {$[\%]$} & {$[\mathrm{n}]$} & {$[\%]$} \\
\hline Not working & 10 & 45 & 5 & 17 & 15 & 29 \\
Working & 12 & 55 & 22 & 73 & 34 & 65 \\
Owning a business & 0 & 0 & 3 & 10 & 3 & 6 \\
\hline Total: & 22 & 100 & 30 & 100 & 52 & 100 \\
\hline p-value=0,04186 (x2 test for "working" and "not working" categories only) & &
\end{tabular}

Persistent ESE makes a big difference when talking about business idea generation. Among those characterized by permanent ESE, having a business idea was very popular (80\%) and conversely, having such an idea was declared by $23 \%$ of these students who constantly lack ESE.

Plans to set up own business in the near future, presented in Table 10, are highly determined by a persistent presence or lack of ESE. Those lacking ESE permanently would not start their own businesses in nearly nine cases out of ten. Students characterized by constant ESE planned to set up businesses quite often $(63 \%)$ and additionally $10 \%$ of them already had a business ${ }^{6}$. Nevertheless, a business owner career was clearly more popular among students showing permanent ESE and they were nearly three times less likely to plan their future as hired employees as compared with their counterparts lacking ESE.

6 Note that ALL student entrepreneurs were characterized by permanent ESE. 
Table 9. Persistent entrepreneurial self-efficacy and business idea generation

\begin{tabular}{lllllll}
\hline \multirow{2}{*}{ Business idea generation } & \multicolumn{2}{l}{ Persistent } & \multicolumn{2}{l}{ Persistent } & \multicolumn{2}{l}{ Total: } \\
& lack of ESE & \multicolumn{2}{l}{ presence of ESE } & & \\
& {$[\mathrm{n}]$} & {$[\%]$} & {$[\mathrm{n}]$} & {$[\%]$} & {$[\mathrm{n}]$} & {$[\%]$} \\
\hline Not having a business idea & 17 & 77 & 6 & 20 & 23 & 44 \\
Having a business idea & 5 & 23 & 24 & 80 & 29 & 56 \\
\hline Total: & 22 & 100 & 30 & 100 & 52 & 100 \\
\hline
\end{tabular}

$p$-value $=0,00004$ ( $\chi 2$ test)

Table 10. Persistent entrepreneurial self-efficacy and plans to set up own business

\begin{tabular}{lllllll}
\hline & \multicolumn{2}{l}{$\begin{array}{l}\text { Persistent } \\
\text { Plans regarding setting up }\end{array}$} & $\begin{array}{l}\text { Persistent } \\
\text { presence of }\end{array}$ & \multicolumn{2}{l}{ Total: } \\
own business & {$[\mathrm{n}]$} & {$[\%]$} & {$[\mathrm{n}]$} & {$[\%]$} & {$[\mathrm{n}]$} & {$[\%]$} \\
\hline $\begin{array}{l}\text { Not planning to set up own business } \\
\text { lack }\end{array}$ & 19 & 86 & 8 & 27 & 27 & 52 \\
$\begin{array}{l}\text { Planning to set up own business } \\
\text { in a few years to come }\end{array}$ & 3 & 14 & 19 & 63 & 22 & 42 \\
Already owning a business & 0 & 0 & 3 & 10 & 3 & 6 \\
\hline Total: & 22 & 100 & 30 & 100 & 52 & 100 \\
\hline p-value=0,00007 (x2 test for "not planning" and "planning" categories only) & &
\end{tabular}

The above-mentioned difference is also visible with regard to future career choice (see Table 11), even though it is less striking mostly due to the fact that quite a lot of students find it difficult to say what kind of career they expect in fifteen years.

Table 11. Persistent entrepreneurial self-efficacy and future career choice

\begin{tabular}{lllllll}
\hline \multirow{2}{*}{ Future career choice } & \multicolumn{2}{l}{ Persistent } & \multicolumn{2}{l}{ Persistent } & \multicolumn{2}{l}{ Total: } \\
& \multicolumn{2}{l}{ lack of ESE } & \multicolumn{2}{l}{ presence of ESE } & \\
& {$[\mathrm{n}]$} & {$[\%]$} & {$[\mathrm{n}]$} & {$[\%]$} & {$[\mathrm{n}]$} & {$[\%]$} \\
\hline Business owner & 4 & 18 & 19 & 63 & 23 & 44 \\
Hired employee & 13 & 59 & 6 & 20 & 19 & 37 \\
Other and no answer & 5 & 23 & 5 & 17 & 10 & 19 \\
\hline Total: & 22 & 100 & 30 & 100 & 52 & 100 \\
\hline p-value=0,00079 (x2 test for "business owner" and "hired employee" categories only)
\end{tabular}




\section{CONCLUSION}

Entrepreneurial self-efficacy manifested by student-beginners seems to influence their later entrepreneurial behavior in a statistically significant way. Those who started their studies and believed they would be able to successfully run their own business, upon their graduation three years later were more oriented towards setting up own business in a few years to come (mostly between 3 to 5 years). Since many of them considered professional experience as something necessary to become a business owner, the majority of them started working part-time or full time even before the graduation. ESE also seems to influence the business idea generation process. Those characterized by ESE more often had a defined business idea, which makes their future business venture more feasible. All of that makes ESE a potentially valuable early predictor of future entrepreneurial activities.

The major limitation of the study is the low number of participants, which does not allow for more sophisticated and in-depth analysis. Despite its preliminary pilot character, this research can be useful for showing new paths and developments. Particularly, it would be very interesting to investigate the reasons for losing (and gaining) ESE during the course of studies. On one hand, reducing the number of ESE-characterized students can sometimes be beneficial, as premature ESE can possibly result in serious problems when a business venture fails (Zięba \& Ziemiański, 2013). On the other hand, preventing students from losing their ESE could increase the number of successful business ventures. If the education process can influence students, in the sense that they lose or gain ESE, then the consequences of this influence should be investigated thoroughly.

\section{References}

Abaho, E., Olomi, D. R., \& Urassa, G. C. (2015). Students' entrepreneurial self-efficacy: Does the teaching method matter? Education + Training, 57(8/9), 908-923.

Arora, P., Haynie, J. M., \& Laurence, G. A. (2013). Counterfactual thinking and entrepreneurial self-efficacy: The moderating role of self-esteem and dispositional effect. Entrepreneurship Theory and Practice, 37(2), 359-385.

Balkin, D. B., \& Baron, R. A. (2002). Inventors and new venture formation: The effects of general self-efficacy and regretful thinking. Entrepreneurship Theory and Practice, 27(2), 149-165.

Bandura, A. (1977). Self-efficacy: Toward a unifying theory of behavioral change. Psychological Review, 84(2), 191-215.

Barakat, S., Boddington, M., \& Vyakarnam, S. (2014). Measuring entrepreneurial self-efficacy to understand the impact of creative 
activities for learning innovation. International Journal of Management Education, 12(3), 456-468.

Boyd, N. G., \& Vozikis, G. S. (1994). The influence of self-efficacy on the development of entrepreneurial intentions and actions. Entrepreneurship Theory and Practice, 18, 63-77.

Carr, J. C., \& Sequeira, J. M. (2007). Prior family business exposure as intergenerational influence and entrepreneurial intent: A theory of planned behavior approach. Journal of Business Research, 60(10), 1090-1098.

Chen, C. C. C., Greene, P. P. G., \& Crick, A. (1998). Does entrepreneurial selfefficacy distinguish entrepreneurs from managers? Journal of Business Venturing, 13(4), 295-316.

Coleman, S., \& Kariv, D. (2014). "Deconstructing" entrepreneurial selfefficacy: A gendered perspective on the impact of ESE and community entrepreneurial culture on the financial strategies and performance of new firms. Venture Capital, 16(2), 157-181.

Cumberland, D. M., Meek, W. R., \& Germain, R. (2015). Entrepreneurial selfefficacy and firm performance in challenging environments: Evidence from the franchise context. Journal of Developmental Entrepreneurship, 20(1), 1550004.

Densberger, K. (2014). The self-efficacy and risk-propensity of entrepreneurs. Journal of Enterprising Culture, 22(4), 437-462.

Din, B. H., Anuar, A. R., \& Usman, M. (2016). The effectiveness of the entrepreneurship education program in upgrading entrepreneurial skills among public university students. Procedia - Social and Behavioral Sciences, 224(August 2015), 117-123.

Drnovšek, M., \& Wincent, J. (2010). Entrepreneurial self-efficacy and business start-up: Developing a multi-dimensional definition. International Journal of Entrepreneurial Behavior \& Research, 16(4), 329-348.

Franco, M., Haase, H., \& Lautenschläger, A. (2010). Students' entrepreneurial intentions: An inter-regional comparison. Education + Training, 52(4), 260-275.

Hsu, D. K., Wiklund, J., \& Cotton, R. D. (2015). Success, failure, and entrepreneurial reentry: An experimental assessment of the veracity of self-efficacy and prospect theory. Entrepreneurship: Theory and Practice, 1(828), 1-29.

Ismail, V. Y., Zain, E., \& Zulihar. (2015). The portrait of entrepreneurial competence on student entrepreneurs. Procedia - Social and Behavioral Sciences, 169, 178-188.

Izquierdo, E., \& Buelens, M. (2011). Competing models of entrepreneurial intentions: The influence of entrepreneurial self-efficacy and attitudes. International Journal of Entrepreneurship and Small Business, 13(1), n/a.

Karlsson, T., \& Moberg, K. (2013). Improving perceived entrepreneurial abilities through education: Exploratory testing of an entrepreneurial selfefficacy scale in a pre-post setting. International Journal of Management Education, 11(1), 1-11. 
Klyver, K., \& Thornton, P. H. (2010). The cultural embeddedness of entrepreneurial self-efficacy and intentions: A cross-national comparison. Academy of Management, Montreal, August.

Krecar, I. M., \& Coric, G. (2013). Changes in entrepreneurial self-efficacy since completion of entrepreneurial studies. Procedia-Social and Behavioral Sciences, 89, 74-78.

Lope Pihie, Z. A., \& Bagheri, A. (2011). Malay secondary school students' entrepreneurial attitude orientation and entrepreneurial self-efficacy: A descriptive study. Journal of Applied Sciences, 11(2), 316-322.

Maresch, D., Harms, R., Kailer, N., \& Wimmer-Wurm, B. (2016). The impact of entrepreneurship education on the entrepreneurial intention of students in science and engineering versus business studies university programs. Technological Forecasting and Social Change, 104, 172-179.

Mortan, R. A., Ripoll, P., Carvalho, C., \& Bernal, M. C. (2014). Effects of emotional intelligence on entrepreneurial intention and self-efficacy. Revista de Psicología Del Trabajo Y de Las Organizaciones, 30(3), 97-104.

Oyugi, J. L. (2015). The mediating effect of self-efficacy on the relationship between entrepreneurship education and entrepreneurial intentions of university students. Journal of Entrepreneurship Management and Innovation, 11(2), 31-56.

Pihie, Z. A. L., \& Bagheri, A. (2013). Students' entrepreneurial regulation and intention to become an entrepreneur: A comparison between public and private universities. South African Journal of Business Management, 44(4), 25-32.

Pihie, Z. A. L., \& Bagheri, A. (2011). Teachers' and students' entrepreneurial self-efficacy: Implication for effective teaching practices. Procedia - Social and Behavioral Sciences, 29, 1071-1080.

Pihie, Z. A. L., \& Bagheri, A. (2013). Self-efficacy and entrepreneurial intention: the mediation effect of self-regulation. Vocations and Learning, 6(3), 385-401.

Piperopoulos, P., \& Dimov, D. (2015). Burst bubbles or build steam? Entrepreneurship education, entrepreneurial self-efficacy, and entrepreneurial intentions. Journal of Small Business, 53(4), 970-985.

Pollack, J. M., Burnette, J. L., \& Hoyt, C. L. (2012). Self-efficacy in the face of threats to entrepreneurial success: Mind-sets matter. Basic and Applied Social Psychology, 34(3), 287-294.

Rachmawan, A., Lizar, A. A., \& Mangundjaya, W. L. . (2015). The role of parent's influence and self-efficacy on entrepreneurial intention. The Journal of Developing Areas, 49(3), 417-430.

Setiawan, J. L. (2014). Examining entrepreneurial self-efficacy among students. Procedia - Social and Behavioral Sciences, 115, 235-242.

Shinnar, R. S., Hsu, D. K., \& Powell, B. C. (2014). Self-efficacy, entrepreneurial intentions, and gender: Assessing the impact of entrepreneurship education longitudinally. International Journal of Management Education, 12(3), 561-570. 
Studdard, N. L., Dawson, M., \& Jackson, N. L. (2013). Fostering entrepreneurship and building entrepreneurial self-efficacy in primary and secondary education. Creative and Knowledge Society, 3(2), 1-14.

Tsai, K.-H., Chang, H.-C., \& Peng, C.-Y. (2016). Extending the link between entrepreneurial self-efficacy and intention: a moderated mediation model. International Entrepreneurship and Management Journal, 12(2), 445-463.

Wang, J.-H., Chang, C.-C., Yao, S.-N., \& Liang, C. (2016). The contribution of self-efficacy to the relationship between personality traits and entrepreneurial intention. Higher Education, 72(2), 209-224.

Wennberg, K., Pathak, S., \& Autio, E. (2013). How culture moulds the effects of self-efficacy and fear of failure on entrepreneurship. Entrepreneurship \& Regional Development, 25(9-10), 756-780.

Yasruddin, A., Yasin, M., Aziz, N. A., Mahmood, N., Azyyati, N., \& Jaafar, N. (2011). Students' entrepreneurial inclination at a Malaysian Polytechnic: A preliminary investigation. International Education Studies, 4(2),198-207. Zięba, K. (2015). Preprzedsiębiorczość. Gdańsk: Wydawnictwo Politechniki Gdańskiej, 2015. Retrieved from http://han.bg.pg.edu.pl/han/ebsco/ search.ebscohost.com/login.aspx?direct=true $\& d b=c a t 04542 a \& A N=b g .0$ 00105109\&lang $=p \mid \&$ site $=$ eds-live

Zięba, K., \& Ziemiański, P. (2013). Poczucie samoskuteczności a nadmierne zaangażowanie w działaniach przedsiębiorców. Model teoretyczny. Zeszyty Naukowe Uniwersytetu Szczecińskiego. Ekonomiczne Problemy Usług, (102 Uwarunkowania rynkowe rozwoju mikro, małych i średnich przedsiębiorstw-Mikrofirma), 196-205.

\section{Abstrakt}

Przez ostatnie czterdzieści lat, które minęło od stworzenia przez Bandurę (1977) koncepcji poczucia samoskuteczności, liczba publikacji wykorzystujqcych tę koncepcję stale rośnie. Jej rozwój doprowadził do powstania skontekstualizowanego konstruktu „przedsiębiorczego poczucia samoskuteczności” - ESE (Chen et al. 1998). Wśród rozmaitych nurtów badawczych zajmujqcych się problematykq ESE można wyróżnić m.in. ten skupiajqcy się na badaniu ESE wśród studentów. W odniesieniu do tego nurtu daje się zaobserwować w ostatnim czasie wyraźnq tendencję do skupiania się na śledzeniu zmian w poziomie ESE zachodzqcych w badanej populacji np. Karlsson, Moberg (2013), Shinnar, Hsu, Powell (2014), Ismail, Zain, Zulihar (2015).

Chcac wypetnić wyraźnq lukę w literaturze naukowej poświęconej badaniu ESE w krajach post-komunistycznych (a w szczególności w Polsce) (Drnovsek, Wincent, Cardon, 2010) i nawiqzujqc do dużego zainteresowania ta problematykq, prezentujemy w niniejszym artykule krótki przeglad badań nad ESE, stawiajqc jednocześnie pytanie czy koncepcja ta może służyćjako wczesny predykator działań przedsiębiorczych polskich studentów, prowadzqcych ostatecznie do preprzedsiębiorczości (nascent entrepreneurship).

Materiał badawczy został zebrany w ramach projektu SEAS (Survey on Entrepreneurial Attitudes of Students), prowadzonego na Wydziale Zarzqdzania i Ekonomii Politechniki Gdańskiej. Próba badawcza obejmuje 72 studentów, którzy byli badani 
pod kq̨tem ESE na poczq̨tku oraz pod koniec studiów z wykorzystaniem pojedynczej skali wykorzystujqcej pięciopunktowq skalę Likerta. Przeprowadzone badanie potwierdza, że poziom ESE w momencie rozpoczynania studiów ma istotne statystycznie znaczenie dla późniejszych zachowań przedsiębiorczych, czyniq̨c ESE wartościowym predykatorem działań przedsiębiorczych absolwentów. W końcowej części artykułu omówiono ograniczenia i potencjalne kierunki dalszych badań.

Słowa kluczowe: poczucie samoskuteczności, przedsiębiorcze poczucie samoskuteczności, przedsiębiorczość.

\section{Biographical notes}

Krzysztof Zięba, Ph.D., D.Sc. works for the Department of Entrepreneurship and Business Law at the Faculty of Management and Economics, Gdansk University of Technology. His main interests include economics of the SME sector, small business management, entrepreneurship and nascent entrepreneurship.

Jakub Golik, M.Sc. is a graduate of applied mathematics and international management from the Gdansk University of Technology. He is a Research \& Teaching Assistant and Ph.D. student at the Department of Entrepreneurship and Business Law at the Faculty of Management and Economics, Gdansk University of Technology. His main research interests are utility-maximizing models in entrepreneurship and measures of risk-propensity. In his free time, Jakub is a cellist and music enthusiast. 
